\title{
Comprehensive Literature Review on Valuable Compounds and Extraction Technologies: The Eastern Baltic Sea Seaweeds
}

\author{
Karīna BĀLIN̦A ${ }^{1 *}$, Kaspars IVANOVS ${ }^{2}$, Francesco ROMAGNOLI ${ }^{3}$, Dagnija BLUMBERGA ${ }^{4}$ \\ 1, 3,4 Institute of Energy Systems and Environment, Riga Technical University, Äzenes iela 12/1, \\ Riga, LV1048, Latvia \\ ${ }^{2}$ Institute of Food Safety, Animal Health and Environment "BIOR”, Lejupes iela 3 Riga, LV1076, Latvia
}

\begin{abstract}
Seaweed valuables have been researched a lot in the last decades but there is a lack of information on brackish seaweed at the eastern part of the Baltic Sea. Previous research shows that Baltic seaweed can be used as a source for phycocolloids as well as for bioenergy. The amount of available usable biomass is not clear, also seaweed in brackish seawater does not reach the dimensions such as the same species in Western parts of the Baltic Sea where the salinity is higher. Therefore, the use of this biomass must be smart to create economic benefit. Three abundant Baltic brackish seaweed species were chosen, to represent green, brown and red seaweed groups and an in-depth information analysis was made to clarify possible focus substances that could be extracted from these species. In this paper we summarize literature of common seaweed components, traditional extraction technology, and potential amount in seaweed and give an overview of novel methods for extraction of seaweed bioactive compounds.
\end{abstract}

Keywords - Bioeconomy; extraction; Fucus vesiculosus; Furcellaria lumbricalis; macroalgae; phytobenthos; Ulva sp.

\section{INTRODUCTION}

Biorefinery is an important part of the biobased economy and biotechonomy integrating different biomass conversion processes to produce energy and value-added products into a single facility. Biotechonomy is the sustainable conversion of a biomass to produce energy, food, feed, pharmaceuticals and other materials [1]-[3]. The production of these products through a biorefinery concept and in compliance with the biotechonomy approach make the cultivation and seaweed processing economically and environmentally feasible, respecting social and policy angles. Nowadays the global biorefinery concept mainly includes terrestrial biomass with plants and forest on top and only a small part has recently been devoted to algae [4].

Marine macroalgae or seaweed have the potential to partly replace terrestrial biomass. With current research going on in this field it is already declared that algae are a third generation bioresource and do not compete with food and feed plants, nor do they use resources for their growth. Valuable substances that can be found in algae can be a way to promising low-carbon

* Corresponding author.

E-mail address: kbalina88@gmail.com 
economy. Seaweed aquaculture is already popular in Asian countries [5], but seaweed natural distribution area covers the world, including Europe and the Baltic Sea [6]. Recently seaweed products have become popular in Europe as a source of polysaccharides for food and pharmaceutical use [7], [8]. The seaweed mineral content is higher than the mineral level in terrestrial plants and animal products [9], [10]. High mineral and low-fat content makes seaweed a suitable feedstock for food and feed.

Even though seaweed compounds have recently been widely researched, there has been lack of information on brackish seaweed naturally growing on the eastern part of the Baltic Sea. In any case, the amount of available biomass is not clear, but it is known that specimens do not develop to a great size as the same species in the Western parts of the Baltic Sea. To gain the maximum benefit from a minimum amount of biomass, a smart biorefinery strategy has to be used.

In this review, a summary of seaweed biorefinery potential compiling the most common seaweed compounds and their contents have been developed. Three Baltic Sea brackish seaweed species were chosen to represent green, brown, and red seaweed groups and an in-depth information analysis was conducted to clarify possible focus substances that could be extracted from these species. Extraction techniques that would allow to use leftover biomass from extraction processes were summarized and discussed.

This review focuses on seaweeds abundant in Eastern Baltic Sea region, where salinity ranges from $5 \%$ to $7 \%$. A comprehensive literature review was done to investigate the potential added value compounds contained in three Eastern Baltic typical seaweed species and their extraction technologies to build the analytical basis for prediction and planning of Baltic seaweed application pathways under the biorefinery concept. An in-depth literature search was done to summarize the research performed on seaweed extraction, and relevant quantitative and qualitative data on seaweed extraction was summarized and combined in tables.

\section{Eastern Baltic Seaweed Potential}

\subsection{Seaweed Components}

Seaweed is composed of a special composition of substances. Even though it is often considered as a close ancestor to terrestrial plants, substances found in seaweed are different [11]. Known for their high nutritional and pharmaceutical value, they are widely consumed as food and as herbal remedies to cure health problems like eczema, psoriasis, renal disorders, digestive system problems, heart and cardiovascular diseases and are even mentioned as a treatment for cancer [12]-[15]. Seaweed use as feed, food, fertilizer, fungicide, herbicide has developed a demand for seaweed as a valuable resource [15]-[17].

Nutrient composition in seaweed varies, depending on the species, time of collection, geographic location and environmental conditions such as temperature, light and nutrient concentration in water. Even the same seaweed genus can have great differences in their nutritional composition.

Seaweed biomass has a high polysaccharide amount (Table 1) that exists in the cell wall structures and has numerous commercial applications in products such as stabilisers, thickeners, emulsifiers, food, feed, beverages, etc [18], [19]. The total amount of polysaccharides can range from $4 \%$ to $76 \%$ of dry weight. 
TABLE 1. MAJOR SACCHARIDES AND POLYSACCHARIDES FOUND IN EACH OF THE THREE TYPES OF SEAWEED [20]

\begin{tabular}{lll}
\hline Green algae & Brown algae & Red algae \\
\hline Cellulose & Cellulose & Cellulose \\
Starch & Laminarin starch & Floridean starch \\
Mannan or galactan & Mannitol (monomer) & Agar \\
Heteroglycan & Alginic acid & Carrageenan \\
Ulvan & Fucoidans & Xylan \\
Xylan & & Galactan \\
\hline
\end{tabular}

Structural features of polysaccharides give them the ability to bind water up to 20 times their weight to give hydrogel, which qualifies them to be referred to as hydrocolloids or phycocolloids. The formation of gel involves non-covalent interaction, such as hydrogen bonding, hydrophobic and ionic interaction among the constituents and are formed from cooling of heated solutions of polymers. Many polysaccharides can form hydrogels by either heating or cooling. The gel is composed of at least two components, where a polymer forms a three-dimensional network in a liquid medium such as water.

The amount of proteins in seaweed varies in relation to surrounding environmental factors and species [21]. Highest protein concentrations are reported in winter and early spring months and lowest concentrations regarding to nitrogen concentrations have been observed from July to October. In general, red and green seaweed have relatively high protein concentrations (10\%-30\% dry matter), while brown seaweed contains an average of $3 \%$ $15 \%$ of dry weight [22]. Brackish red seaweed Furcellaria lumbricalis sometimes is assimilated to Palmaria palmata for which protein content can represent even up to $35 \%$ and $47 \%$ of the dry mass. That is higher protein amount than legumes, like soybean with $35 \%$ of protein in dry mass, meaning it can be alternative dietary addition for vegetarian and vegan diet. The amino acid composition of seaweeds can be compared to other protein sources such as eggs and soybean. For most seaweed, glutamic acid and aspartic acids together make a large part of the total amount of amino acids [21].

As photosynthetic organisms, seaweed contains pigments that are responsible for the variety of colours observed in brown, green and red seaweed. These pigments allow seaweed to absorb the light necessary for photosynthesis at depths that have various degrees of light intensity. These pigments can be divided into three main groups which include chlorophylls, phycobiliproteins and carotenoids and have various health benefits (Table 2).

TABle 2. Dominant Pigments Representing the Three Macroalgae Groups

\begin{tabular}{|c|c|c|c|c|}
\hline Pigment Class & Green Algae & Brown Algae & Red Algae & Reference \\
\hline Chlorophylls & $\begin{array}{l}\text { Chlorophyll a, } \\
\text { Chlorophyll b, } \\
\text { derivatives }\end{array}$ & $\begin{array}{l}\text { Chlorophyll a } \\
\text { Chlorophyll b } \\
\text { Chlorophyll c derivatives }\end{array}$ & $\begin{array}{l}\text { Chlorophylls a } \\
\text { Chlorophyll d } \\
\text { derivatives }\end{array}$ & {$[23]$} \\
\hline Carotenoids & $\begin{array}{l}\alpha, \beta, \gamma \text {-carotene, } \\
\text { Xanthophylls }\end{array}$ & $\begin{array}{l}\text { Fucoxanthin } \\
\text { Xanthophylls } \\
\beta \text {-carotene }\end{array}$ & $\begin{array}{l}\text { Xanthophylls } \\
\alpha, \beta \text {-carotene }\end{array}$ & {$[20],[23]-[25]$} \\
\hline Phycobiliproteins & - & - & $\begin{array}{l}\text { Phycoerythrin } \\
\text { Phycocyanin }\end{array}$ & {$[23],[24]$} \\
\hline
\end{tabular}

Chlorophyll and its derivatives are associated with a number of health benefits including antioxidant and anti-mutagenic activities which may help to prevent cancer [26]. Carotenoids found in seaweed include $\beta$-carotene, fucoxanthin, astaxanthin, violaxanthin, tocopherol, 
zeaxanthin and lutein [19]. Fucoxanthin is another carotenoid present in brown seaweed such as Ascophyllum nodosum and Laminaria digitata [27]. Phycobiliproteins are water-soluble pigments that are found in red seaweed and include phycoerythrin, phycocyanin and allophycocyanin. Previous scientific studies have reported that this group of proteins possess antiinflammatory, liver protecting, anti-viral, anti-tumour, serum lipid reducing and anti-oxidant properties [14]. Phycobiliproteins are found in red seaweed such as Chondrus chrispus and Furcellaria lumbricalis and are responsible for the red-brown colour of these species [28].

Lipids represent only 1-5\% of seaweed dry matter and show a valuable polyunsaturated fatty acid (PUFA) composition particularly regarding with omega-3 and omega- 6 acids which play a role in the prevention of cardio-vascular diseases, osteoarthritis and diabetes. The green algae show interesting levels of alpha linolenic acid. The lipid content in seaweed is very sensitive and has significant differences between species, it also varies by geographical location, season, temperature, salinity and light intensity [29]. Although oxidative stability of PUFAs in brown seaweed lipids is not clear yet, these lipids could be applied to nutraceuticals and functional foods as an oxidative stable omega-3 source.

The mineral composition varies according to genera as well as various other factors such as seasonal, environmental, geographical and physiological variations, as well as the seaweed type such as wild type and cultivated type [15]. Seaweed contains significant amounts of essential minerals ( $\mathrm{Na}, \mathrm{K}, \mathrm{Ca}$, and $\mathrm{Mg}$ ) and trace elements ( $\mathrm{Fe}, \mathrm{Zn}, \mathrm{Mn}$, and $\mathrm{Cu}$ ), which play an important role in building human tissues and regulating vital reactions as related elements of many metalloenzymes due to their cell surface polysaccharides (e.g., agar, carrageenan, alginic acid, alginate, salt of alginate acids, and cellulose), enabling them to absorb inorganic substances from the ambient environment [15]. The mineral content in the form of ash of the seaweed reaches levels of up to $55 \%$ on a dry weight basis.

Phenolic compounds are a group of secondary metabolites comprising a wide variety of compounds produced by both terrestrial and aquatic plants, which include seaweed [30]. One of their most outstanding features is their antioxidant properties, as they prevent the formation of many free radicals because of their metal ion chelating capacity [20], [31]. Phenolic compounds include: flavonoids - that are associated with various bioactivities, including the antioxidant and radical scavenging activity, lignans, tannins, tocopherols, and phenolic acids [32]. Flavonoids that are known as safe and non-toxic antioxidants, have an important function to protect the plant against UV radiation [33]. The capacity of flavonoids to act as antioxidants depends on their molecular structure. The position of hydroxyl groups and other features in the chemical structure of flavonoids are important for their antioxidant and free radical scavenging activities [34].

\subsection{Eastern Baltic Seaweed Biorefinery Potential}

To estimate Baltic seaweed biorefinery potential, the most abundant species were chosen and in-depth literature research was carried out to seek for possible compositions. Findings from researched scientific literature were summarized in Table 3. It must be mentioned that data summarized in this table is not only from seaweed from the Baltic Sea but also from the same species of algae growing around the world. In this way, we can evaluate all potential quantities that could be extracted from these species of seaweed. As mentioned before, seaweed composition can change from season, location, depth and other factors both biotic and abiotic. This table shows all concentrations of the substances that can be expected from these types of biomass. Before commencing any kind of production, it is necessary to carry 
out in-depth composition analysis for locally available seaweed, and repeat analysis 2-4 times through the year to see the composition dynamics during the seasons.

TABle 3. EASTERn BALtiC SEAWEed BIOREFINERy Potential

\begin{tabular}{|c|c|c|c|c|c|c|}
\hline \multirow[b]{2}{*}{ Carbohydrates (\% DW) } & \multicolumn{2}{|c|}{$\begin{array}{l}\text { Green algae } \\
\text { (Ulva intestinalis) }\end{array}$} & \multicolumn{2}{|c|}{$\begin{array}{l}\text { Brown algae } \\
\text { (Fucus vesiculosus) }\end{array}$} & \multicolumn{2}{|c|}{$\begin{array}{l}\text { Red algae } \\
\text { (Furcellaria lumbricalis) }\end{array}$} \\
\hline & 31.34-92 & {$[35]-[39]$} & 65.7 & [7] & 55.4 & \\
\hline Polysacchrides & $4.9-59$ & $\begin{array}{l}{[35],} \\
{[38],} \\
{[40]-[42]}\end{array}$ & $2.31-22$ & [43] & & \\
\hline Agar & & & & & $19-28$ & [44] \\
\hline Alginate & $2-59$ & {$[38]$} & & & & \\
\hline Furcellaran & & & & & $40-50$ & \\
\hline Cellulose & & & & & $3.4-5.7$ & $\begin{array}{l}{[28],} \\
{[45]}\end{array}$ \\
\hline Proteins (\% DW) & $9.49-20.60$ & $\begin{array}{l}{[35],} \\
{[37]-} \\
{[39],} \\
{[41],} \\
{[42],} \\
{[46],[47]}\end{array}$ & $1.4-11.3$ & $\begin{array}{l}{[9],} \\
{[48]}\end{array}$ & $13.1-28$ & $\begin{array}{l}{[28],} \\
{[49]-} \\
{[51]}\end{array}$ \\
\hline \multicolumn{7}{|c|}{ Pigments ( $\%$ of total pigments) } \\
\hline Chl a & 0.394 & {$[52]$} & $0.157-5$ & $\begin{array}{l}{[52],} \\
{[53]}\end{array}$ & 0.228 & {$[52]$} \\
\hline $\mathrm{Chl} \mathrm{b}$ & & & & & 0.078 & \\
\hline $\mathrm{Chl} \mathrm{c}$ & & & 0.035 & [52] & & \\
\hline B carotenoids & & & 0.2 & [53] & $13.3-28.6$ & $\begin{array}{l}{[28],} \\
{[52]}\end{array}$ \\
\hline Fucoxantin & & & 1 & & & \\
\hline R-phycoerythrin & & & & & 0.1 & [28] \\
\hline Xantophyll (mg/kg) & & & & & 32.8 & [50] \\
\hline $\begin{array}{l}\text { Phenolic compounds } \\
\text { (\% ww water extracts) }\end{array}$ & & & 18.4 & $\begin{array}{l}{[20],} \\
{[53],} \\
{[54]}\end{array}$ & $2.25-4.6$ & $\begin{array}{l}{[28],} \\
{[52]}\end{array}$ \\
\hline Lipids (\% DW) & $1.16-22.0$ & $\begin{array}{l}\text { [9], [39], } \\
{[47],} \\
{[55]-[57]}\end{array}$ & $3.95-4.8$ & $\begin{array}{l}{[48]} \\
{[58]}\end{array}$ & $1 \%$ & $\begin{array}{l}{[49],} \\
{[50]}\end{array}$ \\
\hline Fatty acids (FA) & & [9], [55], & & [9], & & [50], \\
\hline$\underline{\text { SFA ( } \% \text { of total FA) }}$ & $25.0-60.6$ & [56], [59] & 24.3 & $\begin{array}{l}{[48],} \\
{[60]}\end{array}$ & 38 & $\begin{array}{l}{[51],} \\
{[60]}\end{array}$ \\
\hline C10:0 & & & $2.8-18.8$ & & & \\
\hline C14:0 & $1.8-5.38$ & & $7.5-13.9$ & & 5.07 & \\
\hline $\mathrm{C} 16: 0$ & $17.9-23.2$ & & $9.6-12.1$ & & 29.36 & \\
\hline MUFA ( $\%$ of total FA) & $21.81-24.8$ & & 47.1 & & 28.80 & \\
\hline $\mathrm{C} 16: 1, \mathrm{n} 7$ & $1.8-6.56$ & & $46.9-31.9$ & & 8.54 & \\
\hline $\mathrm{C} 18: 1, \mathrm{n} 7$ & $7.6-15.2$ & & & & 4.80 & \\
\hline C18:1.n9 & $1.5-5.4$ & & 46.0 & & 10.22 & \\
\hline
\end{tabular}




\begin{tabular}{|c|c|c|c|c|c|c|}
\hline PUFA ( $\%$ of total FA) & \multicolumn{2}{|l|}{$14.8-37.1$} & \multicolumn{2}{|l|}{25.8} & 14.45 & \\
\hline C16:4.n3 & \multicolumn{2}{|l|}{$4.8-10.0$} & & & & \\
\hline C18:2.n6 & \multicolumn{2}{|l|}{$4.6-5.8$} & \multicolumn{2}{|l|}{$7.5-10$} & \multicolumn{2}{|l|}{2.48} \\
\hline $\mathrm{C} 18: 3 . \mathrm{n} 3$ & \multicolumn{2}{|l|}{$8.55-24.1$} & \multicolumn{2}{|l|}{$2.7-3.4$} & \multicolumn{2}{|l|}{2.05} \\
\hline C18:4.n3 & \multicolumn{2}{|l|}{$4.39-14.4$} & \multicolumn{2}{|l|}{2.2} & \multicolumn{2}{|l|}{0.92} \\
\hline C20:4. n6 & \multicolumn{2}{|l|}{$1.4-1.5$} & \multicolumn{2}{|l|}{7.4} & \multicolumn{2}{|l|}{1.63} \\
\hline $\mathrm{C} 20: 5 . \mathrm{n} 3$ & \multicolumn{2}{|l|}{$0.8-5.43$} & \multicolumn{2}{|l|}{$3.7-6.7$} & \multicolumn{2}{|l|}{3.26} \\
\hline Minerals (mg/100g) & & [47], [60] & [6], [7], [70], & & & {$[60]$} \\
\hline $\mathrm{Mg}$ & \multicolumn{2}{|l|}{11} & \multicolumn{2}{|l|}{6.7} & \multicolumn{2}{|l|}{8.9} \\
\hline K & \multicolumn{2}{|l|}{12} & \multicolumn{2}{|l|}{25} & \multicolumn{2}{|l|}{42} \\
\hline $\mathrm{Ca}$ & \multicolumn{2}{|l|}{29} & \multicolumn{2}{|l|}{30} & \multicolumn{2}{|l|}{3.7} \\
\hline $\mathrm{Na}$ & \multicolumn{2}{|l|}{8.5} & \multicolumn{2}{|l|}{18} & \multicolumn{2}{|l|}{10} \\
\hline $\mathrm{P}$ & \multicolumn{2}{|l|}{1.7} & \multicolumn{2}{|l|}{1} & \multicolumn{2}{|l|}{1.2} \\
\hline $\mathrm{Cu}$ & \multicolumn{2}{|l|}{5.7} & \multicolumn{2}{|l|}{3.7} & 6.2 & \\
\hline $\mathrm{Fe}$ & 5800 & & 290 & & 130 & \\
\hline I & 130 & & 260 & & 84 & \\
\hline $\mathrm{Mn}$ & 180 & & 37 & & 7.5 & \\
\hline $\mathrm{Se}$ & 0.76 & & 0.08 & & 0.1 & \\
\hline $\mathrm{Zn}$ & 21 & & 28 & & 23 & \\
\hline Total ASH (\% DW) & $5.42-29.4$ & $\begin{array}{l}{[38],} \\
{[42],} \\
{[46],} \\
{[47],[61]}\end{array}$ & $18.74-30.30$ & $\begin{array}{l}{[7],} \\
{[9],} \\
{[10],} \\
{[54]}\end{array}$ & $9-41$ & $\begin{array}{l}{[45],} \\
{[50],} \\
{[51]}\end{array}$ \\
\hline
\end{tabular}

As illustrated in the table, green algae can be rich with carbohydrates, therefore can be used as a source for cellulose and alginate. Red algae are rich with pigments, that also are valuable antioxidants, therefore can be used for nutritional and pharmaceutical purposes. Values of minerals and phenolic compounds in brown algae show that those could be potential use pathways for these types of seaweed. The amount of the substances detected in the biomass depends mainly on the extraction technologies used.

\section{TEChNOLOGICAL SCHEME OF SEAWEED EXTRACTION}

\subsection{Selection of Criteria for Seaweed Biomass Extraction}

To determine extraction parameters for an application of seaweed extracts it is necessary to define its field of application before using the macroalgae. The degree of purity of the product and impurities are co-factors that determine the national economy sector in which the extract is to be used. In context of biorefinery, the field of application also determines the number of extraction steps, theoretical structure of the plant and technological steps [62], [63]. Seaweed composition varies significantly between species depending on nutrient availability, seasonality and other environmental factors [63], [64]. The choice of species of algae for the desired production is an important factor as it affects not only the ability to produce large-scale biomass but also the composition of valuable compounds under relevant environmental conditions. Although each species of algae offers a unique proportion of proteins, carbohydrates and lipids, some are high in lipids while others are high in protein or 
carbohydrates. Selection criteria should be based on their nutrient content as well as their specific use requirements [65].

The following criteria should be considered when selecting the appropriate algae for food, feed and fuel production:

- Constantly and steadily growing (open pond/sea);

- Produce large-scale biomass;

- Produce high quality and relatively constant ingredients of desirable nutritional value;

- Survive and grow seasonally and with daily climate change;

- Exhibit high photosynthesis efficiency and energy conversion rate;

- Provide minimal dirt from attachment to environment;

- Easy to collect and extract substances [66].

Selection of criteria also includes seaweed harvest, pre-treatment and storage methods [67]. According to the Baltic Marine Environment Protection Commission (HELCOM), the following seaweed species are available for biomass extraction in the Baltic Sea: Furcellaria lumbricalis, Fucus vesiculosus, Cladophora aegagrophila, Laminaria digitata, Chorda filum, Fucus serratus, Chorda tomentosa, Fucus spiralis, Laminaria sacchari [68]. This list includes two of the Eastern Baltic seaweed species used in this research: Furcellaria lumbricalis and Fucus vesiculosus.

In order to obtain the highest quality product, there are several steps to increase efficiency of seaweed extraction (Fig. 1).

\begin{tabular}{|c|c|c|}
\hline \multicolumn{2}{|c|}{ Assessment of geographical availability and mechanical harvesting of algae } \\
\hline Selection of algae or mixture of algae based on 'criteria for seaweed biomass extraction' \\
\hline \multicolumn{3}{|c|}{ Pretreatment methods used (one or more) } \\
\hline \multicolumn{3}{|c|}{ First pretreatment } \\
\hline Washing & Drying & Milling \\
\hline \multicolumn{3}{|c|}{ Secondary pretreatment (concerning extraction process) } \\
\hline Mechanical-physical pretreatment & Chemical pretreatment & Enzymatic pretreatment \\
\hline \multicolumn{3}{|c|}{ Sontraction process; } \\
\hline
\end{tabular}

Fig. 1. Scheme of seaweed handling before extraction.

Extraction process of seaweed can be done in different ways depending on product quality parameters and specific biomolecules needed. Based on previous work [62], it is clear that the use of biorefinery principles is needed to ensure the economical and sustainable extraction of algae products. The conceptual model proposed in the previous work states that a high added value product is obtained and biomass is used with maximum efficiency meaning that physical, chemical and biological transformation processes must operate in a sequential system and in a symbiotic operation to ensure efficient, and hence more profitable, product production [62]. 
Existing scientific literature offers two perspectives on extraction. The first approach is: (a) based on the treatment of substrates under defined conditions with conventional extraction methods, in this case, seaweed extraction to obtain biomolecules, (b) second approach is based on novel extraction techniques and methods that reduce the cost of extraction, reduce the number of extraction steps and increase the yield of biomolecules.

Traditional and innovative methods can be combined to get the best extraction yield at the lowest cost and least impact on the environment. Traditional extraction methods are based on thermomechanical effects and chemical hydrolysis processes, while novel techniques are a significant improvement on existing technologies and are based on the use of physical phenomena (pressure, electric field, ultrasound, microwaves) and biological (enzymes) effects on the matrix [69], [70]. This review article does not address groups of substances or compounds that are relatively unexplored and commercially insignificant.

Just before the extraction of the bioactive substances, it is necessary to process the biomass in order to obtain maximum yield. Secondary pre-treatment methods are divided into three groups of methods that can be used to extract different bioactive substances - lipids, Pigments and sugars [71]:

- Mechanical-physical pre-treatment methods e.g. autoclaving, bead-beating, microwave, sonication, freeze-drying, mechanical crushing, lyophilization and pulsed electric field technology.

- Chemical pre-treatment methods e.g. liquid nitrogen, nitric acid, acetic acid, hydrolysis by $\mathrm{NaOH}, \mathrm{HCl}, \mathrm{H}_{2} \mathrm{SO}_{4}, \mathrm{NaCl}$ solution, nitrous acid.

- Enzymatic pre-treatment methods e.g. cellulase, protease K, driselase, alginate lyase S.

\subsection{Conventional Extraction Techniques}

Conventional extraction methods use organic solvents (i.e. petroleum ether, hexane, cyclohexane, isooctane, toluene, benzene, diethyl ether, dichloromethane, isopropanol, chloroform, acetone, methanol, ethanol etc.) and acids or alkalis, and water. The main purpose of these aggressive substances is to disrupt cell membranes and allow substances contained in the algae to enter the extraction matrix. According to current trends, the solvent used in the extraction process should be cheap and non-toxic [71].

Several types of extraction methods have been used based on the literature on extraction of bioactive compounds from various matrices. Existing conventional extraction methods include:

1. Hydrodistillation;

2. Soxhlet extraction;

3. Maceration;

4. Percolation;

5. Infusion;

6. Decoction; hot continuous extraction [72].

Effectiveness of these methods depends on various influencing parameters, such as solvent properties (polarity, toxicity, volatility, viscosity, and purity), sample size and concentration, particle size, time, polarity of extractant [73], [74]. Drawbacks of conventional techniques are long extraction time, need for very high purity solvents, energy consumption associated with evaporation of a large amount of solvent, relatively low extraction yield, selective and thermolabile degradation of the components used [75]. Traditional extraction methods are relatively well described in scientific literature (lab scale). Environmental policy and resource 
consumption, scientific research viewpoint has advanced green extraction methods (innovative - modern - non-conventional) [69], [70], [75], [76].

Seaweed carbohydrate extraction methods: 1) Food grade - agar, alginate, carrageenan, mannitol; 2) Nonfood grade polysaccharides - fucose-containing sulfated polysaccharides/fucoidan, laminaran, ulvan; their sources, structures and physical properties and uses are well described in Rioux and Turgeon, 2015 [77], in context of hydrocolloids [78] and dietary fibers [76]. Generally, seaweed carbohydrate compounds are extracted using the following methods: i) heating in water; ii) by heating in water with an alkali compound (e.g., sodium bicarbonate) followed by cooling, separation and purification. One of the major drawbacks of the current industrial extraction of seaweed hydrocolloids is the huge time, energy and water consumption. Extraction of seaweed hydrocolloids usually takes 3 hours to achieve optimum yield, depending on the type of hydrocolloids involved. Basically, agar, alginate, and carrageenan extraction should take 2 to 4 hours, but with green methods, it may take up to a few minutes [63], [77], [78]. Seaweed cellulose also belongs to this product group but is not mentioned because existing land-based biomass is a much more accessible and easily obtainable source of cellulose.

Extraction of seaweed proteins, peptides, and amino acids is mainly done on a laboratory scale. Main methods for extracting seaweed protein fractions in the context of traditional methods are solvent extraction, proteolytic hydrolysis (enzymes from microorganisms, plants), hydrolysis by proteolytic microorganisms during fermentation. The overall view of protein in seaweed and extraction methods, is well considered in Pangestuti and Kim, 2015; Bleakley and Hayes, 2017; Kazir et al., 2019 [79]-[81]. Algae proteins are extracted by water, acid and alkali methods followed by several centrifugations, dialysis and recovery steps using methods such as ultrafiltration, precipitation or chromatography. Successful extraction of algae proteins can be greatly influenced by the availability of protein molecules, which are significantly inhibited by high viscosity and anion cell wall polysaccharides such as alginates and carrageenans [80].

Macroalgae are generally considered unsuitable for the production of oil-based products since most species have a low total lipid content $<5 \%$ by weight [64], [82]. Oils from algae, plant biomass are extracted through a variety of methods including organic solvents and water [83]. However, the green extraction process is better suited for low oil oxidation and high yield [84]. The most common traditional lipid extraction methods are water vapour extraction or solvent extraction, such as soxhlet [72].

Seaweed contains a large amount of minerals, up to $30 \%$ of dry weight. Minerals include $\mathrm{Na}, \mathrm{Ca}, \mathrm{Mg}, \mathrm{K}, \mathrm{Cl}, \mathrm{S}$ and $\mathrm{P}$ and trace elements ( $\mathrm{Fe}, \mathrm{Zn}, \mathrm{Mn}, \mathrm{Cu}$ ). Mineral content of seaweed is generally high ( $8-40 \%)$. Minerals and trace elements essential for human consumption are predominantly in brown and red algae [64], [82]. Part of the minerals from the algae biomass can be extracted by incineration and acid treatment of the resulting material [85].

\subsection{Novel Extraction Techniques}

Extraction of biologically active compounds from macroalgae can be conducted through novel methods. These methods are often qualified as green methods. Green methods have several advantages over conventional, including reduced amount of solvent used (including its recovery), shorter time of extraction, and technological performance at lower temperatures. These methods also include improved selectivity for isolation of the desired compounds while avoiding the formation of by-products during extraction and adverse reactions [86]. Most of the extraction methods listed below are considered "green" because they meet the standards that have crystallized in green extraction [87], [88]. Compared to 
conventional extraction methods, the main advantages of innovative extraction methods are higher efficiency, use of water, renewable raw materials, more environmentally friendly treatment conditions, significantly reduced use of hazardous chemicals, safer co-solvents, energy efficiency, reduced derivatives [72]. Based on the reviewed papers and others, there are six novel techniques for biomolecule extraction from seaweed [67], [71], [72], [74], [75], [86], [89]:

- Supercritical fluid extraction (SFE) - SC- $\mathrm{CO}_{2}$;

- Microwave-assisted extraction (MAE);

- Ultrasound-assisted extraction (UAE);

- High-pressure methods (HPM);

- Ionic liquids extraction (ILE);

- Enzymes-assisted extraction (EAE);

- Pulsed electric field extraction (PEF) (see Annex Table 1).

Supercritical fluid extraction $\left(\mathrm{SCF}-\mathrm{CO}_{2}\right)$ applies supercritical fluids to separate compound from matrix using $\mathrm{SC}-\mathrm{CO}_{2}$ as solvent. The most important factors affecting the extraction are pressure, temperature, time and $\mathrm{SC}-\mathrm{CO}_{2}$ flow rate. The prerequisite for the method is extraction in a dry environment where humidity is below $20 \%$ in the extraction matrix. As a result, $\mathrm{SCF}-\mathrm{CO}_{2}$ extracts non-polar materials. The co-solvents used, such as methanol or ethanol, make the spectrum and method of extraction more efficient (for polar materials).

Microwave-assisted extraction (MAE) uses microwaves to warm the solvents in contact with solid matrix to extract contents from the solution. The solvents used, the temperature range, the time of extraction and the power used affect the MAE. This method makes it easier to obtain a spectrum of different polar compounds. The selectivity is affected by the solvent used.

Ultrasound-assisted extraction (UAE) utilizes ultrasound to penetrate solvents in contact with the solid matrix to extract content from the solution. The advantages of the UAE method are the low operating temperatures, efficient cell disruption and various extraction media. Disadvantages are high energy consumption and low extraction volumes, which significantly complicate the technology scale-up.

Enzymatic hydrolysis uses exogenous enzymes to digest material. The efficiency of the method is influenced by the enzyme used, its activity and concentration, temperature, $\mathrm{pH}$. The method is ineffective at elevated temperatures due to enzyme denaturation. Hydrolysis is stopped by heating the material.

High-pressure methods use solvents under critical conditions (increased temperature and/or pressure) to speed up extraction rate of solvents used. There are different variations of high-pressure methods. For example, "Subcritical Water Extraction (SWE)" and "Accelerated Solvent Extraction (ASE)". The influencing parameters are pressure, extraction temperature, solvent concentration and time. In the case of water as a solvent and other solvents, these parameters differ significantly (see Annex Table A1).

Ionic liquid extraction uses specially designed ionic liquids to extract a wide range of compounds. Applied extraction conditions strongly depends on target compound. Pulsed electric field extraction utilizes an electric field to disintegrate cell matrix.

\section{Conclusion}

Literature analysis shows several reviews on extraction of biomolecules from biomass in different contexts, like conventional and novel extraction, as well as pre-treatment of algae 
biomass, compounds from other marine organisms such as fish and crustacean. Our review shows there are many differences in bioactive compounds between Baltic seaweed species. It is possible to extract main seaweed polysaccharides, proteins, lipids, pigments, minerals using novel methods. The studies referred to in this review show the possibility of using eastern Baltic seaweed biomass to extract different kinds of valuables. Even though the quantities of valuables can change a lot due to environmental parameters, this analysis can be used to predict and plan Baltic seaweed application pathways. Novel methods are characterized by more environmentally friendly extraction conditions, high power consumption, need for ongoing optimization of processes. Availability and quality of algae species play an important role in integrating these extraction methods (scale-up). Seaweed biorefinery focuses on single product extraction, newer literature shows increase in products and extraction techniques. For development of more than single phase extraction system, further research in different directions, regarding optimal process parameters, consumption of chemicals (co-solvents), biotechnology and extraction vessels is needed. Our analysis also shows that most extraction processes and results are obtained from laboratory-scale experiments and there is a need for industrial scale data. Limited technologies and unpredictable amounts and quality of seaweed biomass still could be serious problems to limit extraction. This review can be used as a tool to consider ways to apply cascade principle to extraction process.

Still many challenges remain with respect to use of Baltic seaweed for chemical production, such as seaweed availability and large seasonal variation in the chemical and nutritional composition of the seaweed. Seaweed biomass varies between species, locations, season and the yields and type of products obtained are highly dependent on the processing technologies. Further research is suggested to analyse seaweed biomass and change of biomass composition during the different seasons and locations.

\section{REFERENCES}

[1] Pastare L., Romagnoli F. Life Cycle Cost Analysis of Biogas Production from Cerathophyllum demersum, Fucus vesiculosus and Ulva intestinalis in Latvian Conditions. Environmental and Climate Technologies 2019:23(2):258271. https://doi.org/10.2478/rtuect-2019-0067

[2] Zihare L., Gusca J., Spalvins K., Blumberga D. Priorities Determination of Using Bioresources. Case Study of Heracleum sosnowskyi. Environmental and Climate Technologies 2019:23(1):242-256. https://doi.org/10.2478/rtuect$\underline{2019-0016}$

[3] Blumberga D., et al. Energy, Bioeconomy, Climate Changes and Environment Nexus. Environmental and Climate Technologies 2019:23(3):370-392. https://doi.org/10.2478/rtuect-2019-0102

[4] Ree R., Zeeland A. IEA Bioenergy: Task 42 Biorefining. Netherlands: IEA Bioenergy, 2014.

[5] Food and Agriculture Organization of the United Nations. Fishery and Aquaculture Statistics. Rome: FAO, 2011.

[6] NetAlgae. Seaweed Industry in Europe. 2012:11 [Online]. [Accessed 15.04.2020]. Available: www.netalgae.eu

[7] Rioux L.-E., Turgeon S. L., Beaulieu M. Characterization of polysaccharides extracted from brown seaweeds. Carbohydrate Polymers 2007:69(3):530-537. https://doi.org/10.1016/j.carbpol.2007.01.009

[8] Li Y., et al. Optimization study on the hydrogen peroxide pretreatment and production of bioethanol from seaweed Ulva prolifera biomass. Bioresource Technology 2016:214:144-149. https://doi.org/10.1016/j.biortech.2016.04.090

[9] Maehre H. K., et al. Characterization of protein, lipid and mineral contents in common Norwegian seaweeds and evaluation of their potential as food and feed. Journal of the Science of Food and Agriculture 2014:94(15):3281-3290. https://doi.org/10.1002/jsfa.6681

[10] Rupe P., Ruperez P. Mineral content of edible marine seaweeds. Food Chemistry 2002:79(1):23-26. https://doi.org/10.1016/S0308-8146(02)00171-1

[11] Wijayanta A. T., Goto M., Kamiya N. Great potency of seaweed waste biomass from the carrageenan industry for bioethanol production by peracetic acid-ionic liquid pretreatment. Biomass and Bioenergy 2015:81:63-69. https://doi.org/10.1016/j.biombioe.2015.05.023

[12] Taylor S. Marine Medicinal Foods, Volume 64, $1^{\text {st }}$ ed. Implications and Applications, Macro and Microalgae. Elsevier, Academic Press 2011. 
[13] Senthilkumar N., et al. Further studies and biological activities of macromolecular protein R-Phycoerythrin from Portieria hornemannii. International Journal of Biological Macromolecules 2013:62:107-116. https://doi.org/10.1016/j.ijbiomac.2013.08.004

[14] Dumay J., et al. Phycoerythrins: Valuable proteinic pigments in red seaweeds. Advances in Botanical Research 2014:71:321-343. https://doi.org/10.1016/B978-0-12-408062-1.00011-1

[15] Tiwari B. K., Ed. Seaweed Sustainability, $1^{\text {st }}$ ed. Food and Non-Food Applications. Elsevier, Academic Press 2015.

[16] Rajauria G. Seaweeds: A sustainable feed source for livestock and aquaculture. Seaweed Sustainability: Food and NonFood Applications 2015:389-420. https://doi.org/10.1016/B978-0-12-418697-2.00015-5

[17] Bikker P., et al. Biorefinery of the green seaweed Ulva lactuca to produce animal feed, chemicals and biofuels. Journal of Applied Phycology 2016:28:3511-3525. https://doi.org/10.1007/s10811-016-0842-3

[18] Venkatesan J., Anil S., Kim S. K. Eds. Seaweed Polysaccharides, $1^{\text {st }}$ ed. Isolation, Biological and Biomedical Applications. Elsevier, 2017.

[19] Holdt S. L., Kraan S. Bioactive compounds in seaweed: Functional food applications and legislation. Journal of Applied Phycology 2011:23(3):543-597. https://doi.org/10.1007/s10811-010-9632-5

[20] Spurr H. I. Extraction, separation and purification of polyphenols, polysaccharides and pigments from British seaweed for high-value applications. Thesis (PhD), White Rose, 2014.

[21] Fleurence J., Morançais M., Dumay J. Seaweed proteins. In Proteins in Food Processing (Second Edition). Woodhead Publishing Series in Food Science, Technology and Nutrition 2018, 245-262.

[22] Burtin P. Nutritional Value of Seaweeds. Electronic Journal of Environmental, Agricultural and Food Chemistry 2003:2(4):1579-4377.

[23] Werlinger C., Alveal K., Romo H. Biología marina y oceanografia: conceptos y procesos. (Marine biology and oceanography: Concepts and processes.) Chile: University of Consepcion, 2009 (in Spanish)

[24] Bonanno G., Orlando-Bonaca M. Chemical elements in Mediterranean macroalgae. A review. Ecotoxicology and Environmental Safety 2018:148:44-71. https://doi.org/10.1016/j.ecoenv.2017.10.013

[25] Leliaert F., et al. Phylogeny and Molecular Evolution of the Green Algae. Critical Reviews in Plant Sciences 2012:31(1):1-46. https://doi.org/10.1080/07352689.2011.615705

[26] Nunes N., et al. Biochemical composition, nutritional value, and antioxidant properties of seven seaweed species from the Madeira Archipelago. Journal of Applied Phycology 2017:29:2427-2437. https://doi.org/10.1007/s10811-017$\underline{1074-x}$

[27] Milledge J. J., Nielsen B. V., Bailey D. High-value products from macroalgae: the potential uses of the invasive brown seaweed, Sargassum muticum. Reviews in Environmental Science and Biotechnology 2016:15:67-88. https://doi.org/10.1007/s11157-015-9381-7

[28] Kersen P., Paalme T., Pajusalu L., Martin G. Biotechnological applications of the red alga Furcellaria lumbricalis and its cultivation potential in the Baltic Sea. Botanica Marina 2017:60(2):207-218. https://doi.org/10.1515/bot-2016$\underline{0062}$

[29] Sánchez-Machado D. I., et al. Fatty acids, total lipid, protein and ash contents of processed edible seaweeds. Food Chemistry 2004:85(3):439-444. https://doi.org/10.1016/j.foodchem.2003.08.001

[30] Duan X. J., et al. Evaluation of antioxidant property of extract and fractions obtained from a red alga, Polysiphonia urceolata. Food Chemistry 2006:95(1):37-43. https://doi.org/10.1016/j.foodchem.2004.12.015

[31] Yanik J., et al. Pyrolysis of algal biomass. Journal of Analytical and Applied Pyrolysis 2013:103:134-141. https://doi.org/10.1016/j.jaap.2012.08.016

[32] Gomez-Zavaglia A., et al. The potential of seaweeds as a source of functional ingredients of prebiotic and antioxidant value. Antioxidants 2019:8(9):406. https://doi.org/10.3390/antiox8090406

[33] Bergeron C., Carrier D. J., Ramaswamy S. Biorefinery Co-Products: Phytochemicals, Primary Metabolites and ValueAdded Biomass Processing. John Wiley and Sons, Inc., 2012

[34] Meenakshi S., et al. Total flavanoid and in vitro antioxidant activity of two seaweeds of Rameshwaram coast. Global Journal of Pharmacology 2009:3(2):59-66.

[35] Li X., et al. Total fractionation and characterization of the water-soluble polysaccharides isolated from Enteromorpha intestinalis. International Journal of Biological Macromolecules 2018:111:319-325. https://doi.org/10.1016/j.ijbiomac.2018.01.018

[36] Wright R. T., Boorse D. F. Environmental Science: Toward a Sustainable Future, 12th Edition. Upper Saddle River: Pearson Education Inc., 2014.

[37] Peasura N., Laohakunjit N., Kerdchoechuen O., Wanlapa S. Characteristics and antioxidant of Ulva intestinalis sulphated polysaccharides extracted with different solvents. International Journal of Biological Macromolecules 2015:81:912-919. https://doi.org/10.1016/j.ijbiomac.2015.09.030

[38] Kidgell J. T., Magnusson M., de Nys R., Glasson C. R. K. Ulvan: A systematic review of extraction, composition and function. Algal Research 2019:39:101422. https://doi.org/10.1016/j.algal.2019.101422

[39] Szaniawska A., Normant M. Szaniawska, Normant - 2000 - The biochemical composition of Enteromorpha spp. from the Gulf of Gdańsk coast on the southern Balt. Oceanologia 2000:42(1):19-28. 
[40] de Reviers B., Leproux A. Characterization of polysaccharides from Enteromorpha intestinalis (L.) link, chlorophyta. Carbohydrate Polymers 1993:22(4):253-259. https://doi.org/10.1016/0144-8617(93)90128-Q

[41] Tabarsa M., et al. Molecular characteristics and immunomodulatory activities of water-soluble sulfated polysaccharides from Ulva pertusa. Journal of Medicinal Food 2012:15(2):135-144 https://doi.org/10.1089/jmf.2011.1716

[42] Tabarsa M., You S. G., Dabaghian E. H., Surayot U. Water-soluble polysaccharides from Ulva intestinalis: Molecular properties, structural elucidation and immunomodulatory activities. Journal of Food and Drug Analysis 2018:26(2):599-608. https://doi.org/10.1016/j.jfda.2017.07.016

[43] Graiff A., Liesner D., Karsten U., Bartsch I. Temperature tolerance of western Baltic Sea Fucus vesiculosus - growth, photosynthesis and survival. Journal of Experimental Marine Biology and Ecology 2015:471:8-16. https://doi.org/10.1016/j.jembe.2015.05.009

[44] Tuvikene A. R., Robal M. Valgulised pigmendid Läänemere punavetikast Furcellaria lumbricalis : sisaldus ja eraldamisvõimalused. (Proteinic pigments from Baltic red algae Furcellaria lumbricalis: content and isolation possibilities.) Tallin: Tallin University, 2015. (in Estonian)

[45] Bird C. J., Saunders G. W., McLachlan J. Biology of Furcellaria lumbricalis (Hudson) Lamouroux (Rhodophyta: Gigartinales), a commercial carrageenophyte. Journal of Applied Phycology 1991:3(1):61-82. https://doi.org/10.1007/BF00003920

[46] Rahimi F., Tabarsa M., Rezaei M. Ulvan from green algae Ulva intestinalis: optimization of ultrasound-assisted extraction and antioxidant activity. Journal of Applied Phycology 2016:28(5):2979-2990. https://doi.org/10.1007/s10811-016-0824-5

[47] Benjama O., Masniyom P. Nutritional composition and physicochemical properties of two green seaweeds (Ulva pertusa and $U$. intestinalis) from the Pattani Bay in Southern Thailand. Songklanakarin Journal of Science and Technology 2011:33(5):575-583.

[48] Peinado I., Girón J., Koutsidis G., Ames J. M. Chemical composition, antioxidant activity and sensory evaluation of five different species of brown edible seaweeds. Food Research International 2014:66:36-44. https://doi.org/10.1016/j.foodres.2014.08.035

[49] Cherry P., et al. Risks and benefits of consuming edible seaweeds. Nutrition Reviews 2019:77(5):307-329. https://doi.org/10.1093/nutrit/nuy066

[50] Parjikolaei B. R., et al. Valuable Biomolecules from Nine North Atlantic Red Macroalgae: Amino Acids, Fatty Acids, Carotenoids, Minerals and Metals. Natural Resources 2016:7(4):157-183. https://doi.org/10.4236/nr.2016.74016

[51] Naseri A., Holdt S. L., Jacobsen C. Biochemical and Nutritional Composition of Industrial Red Seaweed Used in Carrageenan Production. Journal of Aquatic Food Product Technology 2019:28(9):967-973. https://doi.org/10.1080/10498850.2019.1664693

[52] Dumay J., Morançais M. Proteins and Pigments. In J. Fleurence and I. Levine (Eds.) Seaweed in Health and Disease Prevention, Elsevier Inc. 2016. https://doi.org/10.1016/B978-0-12-802772-1.00009-9

[53] Hermund D. B. Extraction, characterization and application of antioxidants from the Nordic brown alga Fucus vesiculosus. Lyngby: DTU, 2016:312.

[54] Truus K., et al. Analysis of bioactive ingredients in the brown alga Fucus vesiculosus by capillary electrophoresis and neutron activation analysis. Analytical and Bioanalytical Chemistry 2004:379:849-852. https://doi.org/10.1007/s00216-004-2666-2

[55] Rozentsvet O. A., Nesterov V. N. Lipids and fatty acids from Ulva intestinalis from estuaries of the Caspian basin (elton region). Chemistry of Natural Compounds 2012:48(4):544-547. https://doi.org/10.1007/s10600-012-0305-2

[56] Ragonese C., et al. Characterisation of lipid fraction of marine macroalgae by means of chromatography techniques coupled to mass spectrometry. Food Chemistry 2014:145:932-940. https://doi.org/10.1016/j.foodchem.2013.08.130

[57] Jeong G. T., Park D. H. Optimization of lipid extraction from marine green macro-algae as biofuel resources. Korean Journal of Chemical Engineering 2015:32(12):2463-2467. https://doi.org/10.1007/s11814-015-0083-1

[58] Alam M., Chakravarti A., Ikawa M. Lipid composition of the brown alga Fucus vesiculosus. Journal of Phycology 1971:7(3):267-268. https://doi.org/10.1111/j.1529-8817.1971.tb01515

[59] Rohani-Ghadikolaei K., Abdulalian E., Ng W. K. Evaluation of the proximate, fatty acid and mineral composition of representative green, brown and red seaweeds from the Persian Gulf of Iran as potential food and feed resources. Journal of Food Science and Technology 2012:49(6):774-780. https://doi.org/10.1007/s13197-010-0220-0

[60] Biancarosa I., et al. Chemical characterization of 21 species of marine macroalgae common in Norwegian waters: benefits of and limitations to their potential use in food and feed. Journal of the Science of Food and Agriculture 2018:98(5):2035-2042. https://doi.org/10.1002/jsfa.8798

[61] Yin-Hu W., et al. Biomass production of a Scenedesmus sp. under phosphorous-starvation cultivation condition. Bioresource technology 2012:112:193-8. https://doi.org/10.1016/j.biortech.2012.02.037

[62] Balina K., Romagnoli F., Blumberga D. Seaweed biorefinery concept for sustainable use of marine resources. Energy Procedia 2017:128:504-511. https://doi.org/10.1016/j.egypro.2017.09.067

[63] Zollmann M., et al. Green technology in green macroalgal biorefineries. Phycologia 2019:58(5):516-534. https://doi.org/10.1080/00318884.2019.1640516 
[64] Peng Y., et al. Chemical composition of seaweeds. In Seaweed Sustainability, Food and Non-Food Applications 2015:79-124. Elsevier Inc., 2015. https://doi.org/10.1016/B978-0-12-418697-2.00005-2

[65] Rajauria G., et al. Identification and selection of algae for food, feed, and fuel applications. In Seaweed Sustainability, Food and Non-Food Applications 2015:315-345. https://doi.org/10.1016/B978-0-12-418697-2.00012-X

[66] Edwards M. Algal Species Selection. 2010.

[67] Kadam S. U., et al. Processing of seaweeds. In Seaweed Sustainability, Food and Non-Food Applications 2015:61-78, Elsevier Inc., 2015.

[68] HELCOM. Pearls of the Baltic Sea. Networking for life: Special nature in a special sea. Helsinki: HELCOM, 2007

[69] Ledesma-Escobar C. A., de Castro M. D. L. Coverage Exploitation of By-Products from the Agrofood Industry. In Green Extraction of Natural Products: Theory and Practice 2014:265-306. https://doi.org/10.1002/9783527676828.ch8

[70] Cravotto G., Binello A., Orio L. Green extraction techniques. AgroFOOD industry hi-tech 2011:22(6):57-59.

[71] Michalak I., Chojnacka K. Algal extracts: Technology and advances. Engineering in Life Sciences 2014:14(6):581591. https://doi.org/10.1002/elsc.201400139

[72] Sosa-Hernández J. E., et al. State-of-the-art extraction methodologies for bioactive compounds from algal biome to meet bio-economy challenges and opportunities. Molecules 2018:23(11). https://doi.org/10.3390/molecules23112953

[73] Razi Parjikolaei B. et al. Process design and economic evaluation of green extraction methods for recovery of astaxanthin from shrimp waste. Chemical Engineering Research and Design 2017:117:73-82. https://doi.org/10.1016/j.cherd.2016.10.015

[74] Grosso C., Valentão P., Ferreres F., Andrade P. B. Alternative and efficient extraction methods for marine-derived compounds. Marine Drugs 2015:13(5):3182-3230. https://doi.org/10.3390/md1305318

[75] Azmir J., et al. Techniques for extraction of bioactive compounds from plant materials: A review. Journal of Food Engineering 2013:117(4):426-436. https://doi.org/10.1016/j.jfoodeng.2013.01.014

[76] Praveen M. A., et al. An overview of extraction and purification techniques of seaweed dietary fibers for immunomodulation on gut microbiota. Trends in Food Science and Technology 2019:92:46-64. https://doi.org/10.1016/j.tifs.2019.08.011

[77] Rioux L., Turgeon S. L. Seaweed carbohydrates. In Seaweed Sustainability, Food and Non-Food Applications 2015:141-192. https://doi.org/10.1016/B978-0-12-418697-2.00007-6

[78] Abdul Khalil H. P. S., et al. A review of extractions of seaweed hydrocolloids: Properties and applications. eExpress Polymer Letters 2018:12(4):296-317. https://doi.org/10.3144/expresspolymlett.2018.27

[79] Kazir M., et al. Extraction of proteins from two marine macroalgae, Ulva sp. and Gracilaria sp., for food application, and evaluating digestibility, amino acid composition and antioxidant properties of the protein concentrates. Food Hydrocolloids 2019:87:194-203. https://doi.org/10.1016/j.foodhyd.2018.07.047

[80] Bleakley S., Hayes M. Algal Proteins: Extraction, Application, and Challenges Concerning Production. Foods 2017:6(5):33. https://doi.org/10.3390/foods6050033

[81] Pangestuti R., Kim S. Seaweed proteins, peptides, and amino acids. In Seaweed Sustainability, Food and Non-Food Applications 2015:125-140. https://doi.org/10.1016/B978-0-12-418697-2.00006-4

[82] Hamid N., et al. Seaweed minor constituents. In Seaweed Sustainability, Food and Non-Food Applications 2015:193242. https://doi.org/10.1016/B978-0-12-418697-2.00008-8

[83] Chemat F., Cravotto G. Enhancing Extraction Processes in the Food Industry. CRC Press, 2011.

[84] Ivanovs K., Blumberga D. Extraction of fish oil using green extraction methods: A short review. Energy Procedia 2017:128:477-483. https://doi.org/10.1016/j.egypro.2017.09.033

[85] Gribovskaya I. V., Gladchenko I. A., Zinenko G. K. Extraction of mineral elements from inedible wastes of biological components of a life-support system and their utilization for plant nutrition. Advances in Space Research 1996:18(4 5):93-97. https://doi.org/10.1016/0273-1177(95)00865-C

[86] Ciko A. M., Jokić S., Šubarić D., Jerković I. Overview on the application of modern methods for the extraction of bioactive compounds from marine macroalgae. Marine Drugs 2018:16(10):348. https://doi.org/10.3390/md16100348

[87] Chemat F., Vian M. A., Cravotto G. Green extraction of natural products: Concept and principles. International Journal of Molecular Sciences 2012:13(7):8615-8627. https://doi.org/10.3390/ijms1307861

[88] Allaf T., Allaf K. Fundamentals of Process-Intensification Strategy for Green Extraction Operations. In Green Extraction of Natural Products: Theory and Practice 2014:145-172. https://doi.org/10.1002/9783527676828.ch5

[89] Kadam S. U., et al. Extraction of biomolecules from seaweeds. Seaweed Sustainability 2015:243-269. https://doi.org/10.1016/B978-0-12-418697-2.00009-X

[90] Quitain A. T., Kai T., Sasaki M., Goto M. Supercritical carbon dioxide extraction of fucoxanthin from undaria pinnatifida. Journal of Agricultural and Food Chemistry 2013:61(24):5792-5797. https://doi.org/10.1021/jf400740p

[91] Heffernan N., et al. Comparison of extraction methods for selected carotenoids from macroalgae and the assessment of their seasonal/spatial variation. Innovative Food Science and Emerging Technologies 2016:37(B):221-228 https://doi.org/10.1016/j.ifset.2016.06.004

[92] Sivagnanam S. P., et al. Biological properties of fucoxanthin in oil recovered from two brown seaweeds using supercritical CO2 extraction. Marine Drugs 2015:13(6):3422-3442. https://doi.org/10.3390/md13063422 
[93] Michalak I., et al. Supercritical fluid extraction of algae enhances levels of biologically active compounds promoting plant growth. European Journal of Phycology 2016:51(3):243-252. https://doi.org/10.1080/09670262.2015.1134813

[94] Zhang R., et al. A comparative assessment of the activity and structure of phlorotannins from the brown seaweed Carpophyllum flexuosum. Algal Research 2018:29:130-141. https://doi.org/10.1016/j.algal.2017.11.027

[95] Magnusson M., et al. A comparative assessment of microwave assisted (MAE) and conventional solid-liquid (SLE) techniques for the extraction of phloroglucinol from brown seaweed. Algal Research 2017:23:28-36. https://doi.org/10.1016/j.algal.2017.01.002

[96] Quitain A. T., Kai T., Sasaki M., Goto M. Microwave-hydrothermal extraction and degradation of fucoidan from supercritical carbon dioxide deoiled Undaria pinnatifida. Industrial and Engineering Chemistry Research 2013:52(23):7940-7946. https://doi.org/10.1021/ie400527b

[97] Yuan Y., et al. Microwave assisted hydrothermal extraction of polysaccharides from Ulva prolifera: Functional properties and bioactivities. Carbohydrate Polymers 2018:181:902-910. https://doi.org/10.1016/j.carbpol.2017.11.061

[98] Romarís-Hortas V., Moreda-Piñeiro A., Bermejo-Barrera P. Microwave assisted extraction of iodine and bromine from edible seaweed for inductively coupled plasma-mass spectrometry determination. Talanta 2009:79(3):947-952. https://doi.org/10.1016/j.talanta.2009.05.036

[99] Wang F., et al. Ultrasound-assisted extraction and purification of taurine from the red algae Porphyra yezoensis. Ultrasonics Sonochemistry 2015:24:36-42. https://doi.org/10.1016/j.ultsonch.2014.12.009

[100] Mittal R., et al. Ultrasound assisted methods for enhanced extraction of phycobiliproteins from marine macro-algae, Gelidium pusillum (Rhodophyta). Ultrasonics Sonochemistry 2017:38:92-103. https://doi.org/10.1016/j.ultsonch.2017.02.030

[101] Lee S. H., et al. Potential use of ultrasound in antioxidant extraction from Ecklonia cava. Algae 2013:28(4):371-378. https://doi.org/10.4490/algae.2013.28.4.371

[102] Kadam S. U., et al. Laminarin from Irish Brown Seaweeds Ascophyllum nodosum and Laminaria hyperborea: Ultrasound Assisted Extraction, Characterization and Bioactivity. Marine Drugs 2015:13(7):4270-4280. https://doi.org $/ 10.3390 / \mathrm{md} 13074270$

[103]Dang T. T., et al. Optimisation of ultrasound-assisted extraction conditions for phenolic content and antioxidant activities of the alga Hormosira banksii using response surface methodology. Journal of Applied Phycology 2017:29(6):3161-3173. https://doi.org/10.1007/s10811-017-1162-y

[104] Saravana P. S., et al. Evaluation of the chemical composition of brown seaweed (Saccharina japonica) hydrolysate by pressurized hot water extraction. Algal Research 2016:13:246-254. https://doi.org/10.1016/j.algal.2015.12.004

[105]Plaza M., et al. Facts about the formation of new antioxidants in natural samples after subcritical water extraction. Food Research International 2010:43(10):2341-2348. https://doi.org/10.1016/j.foodres.2010.07.036

[106] Anaëlle T., et al. Green improved processes to extract bioactive phenolic compounds from brown macroalgae using Sargassum muticum as model. Talanta 2013:104:44-52. https://doi.org/10.1016/j.talanta.2012.10.088

[107] Sánchez-Camargo A. D. P., et al. Considerations on the use of enzyme-assisted extraction in combination with pressurized liquids to recover bioactive compounds from algae. Food Chemistry 2016:192:67-74. https://doi.org/10.1016/j.foodchem.2015.06.098

[108] Hammed A. M., et al. Enzyme aided extraction of sulfated polysaccharides from Turbinaria turbinata brown seaweed. International Food Research Journal 2017:24(4):1660-1666.

[109] Vo Dinh T., Saravana P. S., Woo H. C., Chun B. S. Ionic liquid-assisted subcritical water enhances the extraction of phenolics from brown seaweed and its antioxidant activity. Separation and Purification Technology 2018:196:287299. https://doi.org/10.1016/j.seppur.2017.06.009

[110]Yi J., Dong B., Jin J., Dai X. Effect of increasing total solids contents on anaerobic digestion of food waste under mesophilic conditions: Performance and microbial characteristics analysis. PLoS ONE 2014:9(7):e102548. https://doi.org/10.1371/journal.pone.0102548

[111] Gereniu C. R. N., Saravana P. S., Chun B. S. Recovery of carrageenan from Solomon Islands red seaweed using ionic liquid-assisted subcritical water extraction. Separation and Purification Technology 2018:196:309-317. https://doi.org/10.1016/j.seppur.2017.06.055

[112] Bozinou E., et al. Pulsed Electric Field Extraction and Antioxidant Activity Determination of Moringa oleifera Dry Leaves: A Comparative Study with Other Extraction Techniques. Beverages 2019:5(1):8. https://doi.org/10.3390/beverages5010008 


\section{ANNEX}

\section{Table A1. Overview of Novel Methods for Seaweed Bioactive Compound EXtraction}

\begin{tabular}{|c|c|c|c|c|}
\hline $\begin{array}{l}\text { Extraction technique } \\
\text { Conditions (C) and influencing parameters } \\
\text { (IP) }\end{array}$ & Seaweed species under investigation & Extracted bioactive compounds & Application outlook & References \\
\hline $\begin{array}{l}\text { Supercritical } \mathrm{CO}_{2}\left(\mathrm{SC}-\mathrm{CO}_{2}\right) \\
\text { (C) Pressure } 9.1-40 \mathrm{MPa}, \mathrm{Temp} .25-75{ }^{\circ} \mathrm{C} \text {, } \\
\text { Time } 50-360 \mathrm{~min} \text {, } \\
>2 \mathrm{~mL} \mathrm{CO}_{2} / \mathrm{min} \\
\mathrm{Co} \text {-solvents: } \\
\text { EtOH } 0.5-15 \% \\
\text { Sunflower, soybean, canola oil } 0.5-2 \% . \\
\text { (IP) Water \%, T }{ }^{\circ} \mathrm{C} \text {, pressure. Flow of } \mathrm{CO}_{2} \text {; } \\
\text { Extraction type: continuous, co-solvent, } \\
\text { soaking. }\end{array}$ & $\begin{array}{l}\text { Cladophora glomerata, Chara fragilis, } \\
\text { Chondrus crispus, Dictyopteris } \\
\text { membranacea, Fucus serratus, } \\
\text { Gracilaria mammillaris, Hypnea charoides, } \\
\text { Hypnea spinella, Halopytis incurvus, } \\
\text { Porphyra sp., Laminaria digitata, } \\
\text { Sargassum muticum, Sargassum vulgare, } \\
\text { Ulva clathrata } \\
\text { Undaria pinnatifida, Polysiphoniucoides, } \\
\text { Saccharina japonica, Sargassum horneri, } \\
\text { Undaria pinnatifida, Ulva flexuosa, }\end{array}$ & $\begin{array}{l}\text { Fucoxanthin, polyphenols, } \\
\text { phlorotannins, carotenoids, } \\
\text { pigments, fatty acids, cytokinins, } \\
\text { auxins, microelements, } \\
\text { macroelements }\end{array}$ & $\begin{array}{l}\text { High investment cost; } \\
\text { Operates in elevated } \\
\text { pressure (safety); } \\
\text { High power } \\
\text { consumption. }\end{array}$ & $\begin{array}{l}{[84],[86]} \\
{[90]-[93]}\end{array}$ \\
\hline $\begin{array}{l}\text { Microwave-assisted extraction (MAE) } \\
\text { (C) Power } 300-1000 \mathrm{~W} \text {; } \\
\text { Frequency }-2450 \mathrm{MHz} \text {; } \\
\text { Temperature }-10-185{ }^{\circ} \mathrm{C} \text {; } \\
\text { Solvents - EtOH, } \mathrm{H}_{2} \mathrm{O} \text {, acetone, propanol, } \\
\text { ethyl acetate, } 0.1 \mathrm{M} \mathrm{HCl} \text {, petroleum ether, } \\
\text { ethyl acetate; } \\
\text { Time - 2-30 min. } \\
\text { (IP) Particle size, solvent used, time, capacity, } \\
\text { and frequency of microwave }\end{array}$ & $\begin{array}{l}\text { Ascophyllum nodosum, Carpophyllum } \\
\text { flexuosum, Carpophyllum plumosum, } \\
\text { Caulerpa racemose, Carpophyllum } \\
\text { flexuosum, Ecklonia radiata, Enteromorpha } \\
\text { prolifera, Fucus vesiculosus, Padina } \\
\text { pavonica, Sargassum thunbergii, } \\
\text { Monostroma latissimum, Ulva meridionalis, } \\
\text { Ulva ohnoi, Ulva prolifera, Undaria } \\
\text { pinnatifida, }\end{array}$ & $\begin{array}{l}\text { Polysaccharides, alkaline, } \\
\text { galactans, carrageenans, agar, } \\
\text { phlorotannins, phloroglucinol, } \\
\text { iodine, bromine, phenols, } \\
\text { phytosterols, phytol }\end{array}$ & $\begin{array}{l}\text { Hard to scale up; } \\
\text { Generation of heat leads } \\
\text { to degradation of } \\
\text { thermolabile compounds; } \\
\text { Low efficiency when } \\
\text { using volatile solvents. }\end{array}$ & $\begin{array}{l}{[86],[94]-} \\
{[98]}\end{array}$ \\
\hline Ultrasound-assisted extraction (UAE) & $\begin{array}{l}\text { Hormosira banksia, Ascophyllum nodosum, } \\
\text { Ascophyllum nodosum, Laminaria } \\
\text { hyperborean, Ecklonia cava, Gelidium }\end{array}$ & $\begin{array}{l}\text { Polyphenols, laminarin, } \\
\text { phycobili-proteins, taurine, }\end{array}$ & $\begin{array}{l}\text { High power consumption } \\
\text { and difficult to scale up. }\end{array}$ & [99]-[103] \\
\hline
\end{tabular}




\begin{tabular}{|c|c|c|c|c|}
\hline $\begin{array}{l}\text { (C) Ultrasound Equipment - Ultrasonic bath, } \\
\text { Ultrasound probe; } \\
\text { Frequency }-20-60 \mathrm{kHz} \text {; } \\
\text { Power - } 100-750 \mathrm{~W} \text {; } \\
\text { Temperature }-20-60{ }^{\circ} \mathrm{C} \text {; } \\
\text { Time - } 2-720 \mathrm{~min} \text {; } \\
\text { Solvents: ethanol, } 0,03 \mathrm{M} \mathrm{HCl} \text {, methanol, } \\
\text { water; } \\
\text { Small sample }-1-10 \mathrm{~g} \text {. } \\
\text { (IP) Ultrasonic frequency, power, time and } \\
\text { medium. }\end{array}$ & $\begin{array}{l}\text { pusillum, Sargassum muticum, Osmundea } \\
\text { pinnatifida, Codium tomentosum, Laurencia } \\
\text { obtuse, Porphyra yezoensis }\end{array}$ & $\begin{array}{l}\text { fucose, uronic acid, antioxidants, } \\
\text { prebiotic compounds }\end{array}$ & & \\
\hline $\begin{array}{l}\text { High pressure methods } \\
\text { "Subcritical Water Extraction (SWE)" } \\
\text { "Pressurized liquid extraction (PLE)" } \\
\text { "Accelerated solvent extraction (ASE)" } \\
\text { (C) Water extraction: } \\
\text { Pressure }-1.3-52 \mathrm{MPa} \text {; } \\
\text { Temperature }-50-420{ }^{\circ} \mathrm{C} \text {; } \\
\text { Time }-5-25 \mathrm{~min} \text {; } \\
\text { Solvent Extraction: } 50-200{ }^{\circ} \mathrm{C} ; 3.5-20 \mathrm{MPa} \\
(\mathrm{IP}) \text { Temperature }\left({ }^{\circ} \mathrm{C}\right) \text {, solvent concentration } \\
(\%) \text {, static time (min), pressure (psi), weight of } \\
\text { sample (g), and flush volume }(\%) \text {. }\end{array}$ & $\begin{array}{l}\text { Ascophyllum nodosum, Fucus spiralis, } \\
\text { Codium fragile, Cystoseira abies-marina, } \\
\text { Sargassum muticum, Padina pavonica, } \\
\text { Fucus serratus, Laminaria digitata, } \\
\text { Gracilaria gracilis, Porphyra spp., } \\
\text { Sargassum vulgare, Undaria pinnatifida, } \\
\text { Halopitys incurvus, Himanthalia elongate, } \\
\text { Pelvetia canaliculata, Ulva intestinalis. } \\
\text { Saccharina japonica, Ulva lactuca, Fucus } \\
\text { vesiculosus, Dictyota dichotoma, Cystoseira } \\
\text { baccata, Himanthalia elongate }\end{array}$ & $\begin{array}{l}\text { Polyphenols, phlorotannins, } \\
\text { fucoidan, total organic carbon, } \\
\text { minerals, monosaccharides, } \\
\text { amino acids, polar compounds; } \\
\text { fatty acids }\end{array}$ & $\begin{array}{l}\text { Not suitable for } \\
\text { thermolabile compounds; } \\
\text { Less selective than SFE. }\end{array}$ & $\begin{array}{l}{[86],[104]-} \\
{[106]}\end{array}$ \\
\hline $\begin{array}{l}\text { Enzyme-assisted extraction (EAE) } \\
\text { (C) Time } 1-4 \mathrm{~h} \\
\text { Temperature } 40-60{ }^{\circ} \mathrm{C} \\
\text { The ratio of enzyme to substrate } \sim 0.5-5 \% \\
\text { (IP) Type, activity and } \\
\text { amount of enzyme used, pH. } \\
\text { Absence of endogenous enzymes. }\end{array}$ & $\begin{array}{l}\text { Sargassum horneri,brown seaweeds, } \\
\text { Undaria pinnatifida, Sargassum coreanum }\end{array}$ & $\begin{array}{l}\text { Antioxidants, fucoxanthin, fatty } \\
\text { acids, polysaccharides }\end{array}$ & $\begin{array}{l}\text { Costs of enzymes are } \\
\text { very high; } \\
\text { Selectivity of enzymes. }\end{array}$ & {$[107],[108]$} \\
\hline
\end{tabular}


$2020 / 24$

\begin{tabular}{|c|c|c|c|c|}
\hline $\begin{array}{l}\text { Ionic liquids extraction (ILE) } \\
\text { (C) Chemicals: For phenolic extraction } 0.5 \mathrm{M} \\
\text { [C4C lim][BF4], } \\
\text { 1:32 w/v mixing ratio; } \\
\text { time } 24 \mathrm{~h} \text {, stirring at } 500 \mathrm{rpm} \text {; } \\
\text { Optional extraction vessel and pressure. } \\
\text { Extraction conditions (ionic liquids used) } \\
\text { strongly depends on target compound. } \\
\text { (IP) Chemicals, vessel, pressure used. }\end{array}$ & $\begin{array}{l}\text { Kappaphycus alvarezii, } \\
\text { S. japonica }\end{array}$ & $\begin{array}{l}\text { Phenolic compounds, } \\
\text { polysaccharides, carrageenan, } \\
\text { terpenoids, alkaloids }\end{array}$ & $\begin{array}{l}\text { Some ILEs require } \\
\text { purification process }\end{array}$ & {$[109]-[111]$} \\
\hline $\begin{array}{l}\text { Pulsed electric fields (PEFs) } \\
\text { (C) field strength of } 0.5-1.0 \mathrm{kV} / \mathrm{cm} \\
\text { treatment time } 100-10,000 \mu \mathrm{s} \text { or } 1-10 \mathrm{kV} / \mathrm{cm} \\
\text { and shorter time }(5-100 \mu \mathrm{s}) \\
\text { (IP) Field strength, time, conductivity of intact } \\
\text { and disintegrated cells }\end{array}$ & - & Phenols, proteins & $\begin{array}{l}\text { Optimization of process } \\
\text { by using different } \\
\text { parameters is needed. } \\
\text { These include pulse } \\
\text { duration, pulse interval, } \\
\text { electric field strength, or } \\
\text { other electrical pulse } \\
\text { shapes. }\end{array}$ & [74], [112] \\
\hline
\end{tabular}

